\title{
Traces in the Archive: Re-imagining Sofia Kovalevskaya
}

Maria Tamboukou, University of East London, UK

Abstract: In this paper I draw on my research project of writing a feminist genealogy of automathographies, through excavating Sofia Kovalevskaya's auto/biographical documents. As the first woman to hold a chair in mathematics in modern Europe, but also as a novelist and playwright, Kovaleskaya is a figure that has inspired generations of women mathematicians, as well as feminist and literary scholars around the world. And yet, apart from her autobiography of her early years in Russia her personal diaries, journals and letters have never been translated in their entirety and remain inaccessible to non-Russian speaking scholars. What has emerged instead from the significant body of secondary literature that has evolved around her life and work is a meta-archive of scattered auto/biographical documents with different and often competing translations, fragments of lines, extracts and passages from her letters, diary entries, as well as novels and plays that create palimpsests of traces of the self. In addressing questions arising from working with fragments and traces of the self, I consider the importance of creative imagination in forming entanglements between the researcher and her archival figures. In this light archival research is configured as a process of doing, learning and understanding, an ongoing becoming emerging after layers of documents have been assembled, organized, reordered, read, transcribed, translated and effectively rewritten.

Key words: automathographies, archival figures, creative imagination, Kovalevskaya, metaarchive, traces, women in mathematics

'My real life begins' (Kovaleskaia 1951, 223) Sofia Kovalevskaya ${ }^{1}$ wrote to her sister Anyuta ${ }^{2}$ on September 29, 1868 from St Petersburg, soon after she had moved there from her country home in Palibino with her newly-wed husband Vladimir Kovalevskii ${ }^{3}$. Interestingly enough, Sofia's 'real life' began on the aftermath of a fictitious marriage and it is this strange entanglement between fiction and reality that I will take up as my starting point in this paper, where I follow wandering trails in the meta-archive ${ }^{4}$ of the first woman to hold a chair in Mathematics in modern Europe. The paper draws on my research project of writing a feminist genealogy of 'automathographies', a notion I have borrowed from Paul Halmos' influential book, I want to be a mathematician: an automathography (1985). This is an interdisciplinary research project that looks into the socio-historical, political and cultural conditions of women's exclusion, marginalization and mis-representation in the field of mathematics, particularly focusing on their 'ego documents': autobiographies, autobiographical fiction, diaries and letters. ${ }^{5}$

Emerging from this project, the paper unfolds in two parts: first I make a cartography of trails and traces within the meta-archive that has been created around Sofia's life and work, including memoirs and biographies, autobiographies and autobiographical fiction, epistolary 
fragments, dispersed diary entries, as well as different and differing translations of her 'ego documents'. In throwing light in some moments of Sofia's meta-archive I try to reveal some layers of the multiple and often conflicting translations, interpretations and discourses that have constructed Sofia Kovalevskaya as a subject. In doing this I have created a compilation of all the citations that my archival and literature research has encountered. It goes without saying that this compilation is an open process, if we consider that Sofia's personal papers in the Russian and Swedish archives have yet to be translated or otherwise become accessible to wider audiences and scholars. ${ }^{6}$

In the second part I look back at Sofia's life as 'a design that has a meaning' following Arendt's insights in life writing (2000). As Julia Kristeva has commented, Arendt was 'a fervent admirer of the "narrated life", of bios-graphie'. $(2001,6)$ Arendt's take on biography however is quite unique. Life histories generate meaning, but this meaning is only accessible to the tellers and listeners of the stories, not to their protagonists. This is because human beings live fragmented lives, whose meaning always evades them: 'the complete sense of an acting individual is provided by the historian or storyteller, who is external to the sphere of pure action' Guaraldo has pithily noted, (2001, p.40). It is this idea of a life lived as action that can be narrativized and shared by others who did not necessarily participate in the narrated action that makes the Arendtian conceptualization of narratives so compelling and unique. In this context, it is the responsibility of the researcher to write about a life, creating forceful connections between life histories and the discourse of history, women's involvement in the history of sciences in the case of this paper.

In thus following Arendt'a approach to life narratives, I theorise the archive as an open process and consider the role of creative imagination in working with fragmented and dispersed auto/biographical documents. ${ }^{7}$ As I have written elsewhere at length, archival research is a question of becoming organically entangled with the spatial, temporal and material rhythms of the archive. (Tamboukou 2020) As a dynamic space, both real and virtual, the archive is traversed and indeed constituted by multiple rhythms and is always open to new ideas and encounters, which keep interrogating, problematizing and changing discourses and practices within the field of life writing and beyond.

\section{Too much happiness?}

On February 10, 1891 Sofia died from pneumonia at her home in Stockholm. 'Too much happiness' were her last words in memories recounted by Thérèse and Elda Gyldén, who were at her bedside. (in Kochina 1985, 282) ${ }^{8}$ Over the years of intense scholarship about and around Kovalevskaya, 'too much happiness' has become a catchphrase, an irony almost, encapsulating the tragic fate of a heroine for women aspiring to a career in science and mathematics, then and now. ${ }^{9}$ Leaving aside the question of whether 'happiness' was indeed amongst Sofia's last words, I want to unravel this thread in the auto/biographical discourses that are interwoven in the fabric of her life. From the end to the beginning then.

Sofia Vasilevna Korvin-Krukovskaia was born in Moscow on January 15, 1851, the second child of a Russian aristocratic family. According to her memoirs, her early years were not happy, as she constantly felt unwanted among her elder sister and younger brother: 'I have often heard 
Nanny say that Anyuta and Fedya are Mama's favorites, while I am -not loved.' ${ }^{10}$ This feeling of 'not being loved' has become a refrain not only in Sofia's ego documents, but also in the biographical tales, memoirs and discourses that have unfolded around her after her untimely death. Her 'emotional insecurity' deriving from these early childhood feelings recounted in her autobiography, have also coloured the ways her relationship with her 'fictitious' husband has been perceived and discussed:

When in aftertimes Sonia spoke to me about her past life, her bitterest complaint was 'Nobody has really loved me!' And when I objected, but your husband did love you most fondly and truly, she always said, 'He only loved me when I was with him, but he could do quite well without me.' (Lermontova 1951, 384) $)^{11}$

This extract from lulia Lermontova's memoir, folded within Anna Carlotta Leffler's biography, is indicative of the different layers of auto/biographical discourses that have revolved around Sofia. Iulia (1847-1919) was Sofia's close friend and the first woman in the world to get a PhD in Chemistry from the University of Göttingen in 1874. She studied in Germany alongside Sofia and the only way both young women realized their dreams of university studies was by escaping Russia through 'a fictitious marriage. ${ }^{12}$ Although upper class women in Russia in the 1860 's had more legal rights in terms of property and inheritance than their counterparts in Europe (see Rosslyn 2003, 8-9), they were under parental and/or marital control. Their mobility was seriously restricted as they could not work, study or live apart from their male guardians, whether fathers or husbands. But there was an air of freedom in the $1860 \mathrm{~s}$ in Russia, particularly among the younger generation, who strongly came to believe that scientific knowledge would end the dark ages of humanity and would open up the road to social revolution:

We were so enthusiastic about the new ideas; so sure that the present social state could not continue long. We pictured to ourselves the glorious period of liberty and universal enlightenment of which we dreamed, and in which we firmly believed. Besides this, we had the sense of true union and cooperation. When three or four of us met in a drawingroom among older people, where we had no right to advance our opinions, a tone, a glance, even a sigh, were sufficient to show one another that we were one in thought and sympathy. (Sofia in Leffler 1895b, 161)

Education as a route to equality was at the heart of this movement, but women's access to university studies was still extremely limited in Russia, and not officially sanctioned. Some women were allowed to audit lectures in scientific courses at St Petersburg university, depending on the views of the professors and lecturers. However, as student uprisings started erupting in different universities at the time, an era of reaction began, which dashed revolutionary hopes. And yet there were many young men in Russia's radical circles, who were committed to support women in their struggle to equality. ${ }^{14}$ One way to do this was through consenting to enter fictitious marriages, thus offering women the opportunity to take control of their lives and pursue university degrees abroad.

Vladimir Kovalevskii was among those radical young men, determined to sacrifice himself to 'the common cause'. When approached by Anyuta about the possibility of a 'fictitious marriage', he accepted on the condition that his 'bride' would be her younger sister, Sofia. 
His willingness to support the cause was not altogether sacrificial, since at the time he was himself in the process of pursuing doctoral studies in paleontology. ${ }^{15}$

Despite difficulties and opposition from her family, particularly in the light of her young age, Sofia and Volodya, Vladimir's nickname, got married in September 1867. Writing to her sister in St Petersburg, while preparing her 'wedding' at Palibino, Sofia gave a simple outline of how she imagined her future life: 'When I think of asceticism, I always imagine a small and very poor room in Heidelberg, very difficult and serious work and no society, I live alone' (in Kochina 1985, 47) The newly married couple moved to St Petersburg, where Sofia started attending lectures in medicine. But as the opportunity of university studies for women had almost become impossible at the time, Sofia followed a wave of young women students who were flocking to European universities at the time in pursuit of a higher degree: 'I will not wait, I want to go abroad and study with you lulia; I cannot imagine a happier existence than a quiet, modest life in some forgotten corner of Germany or Switzerland, among books and studies' (Kovaleskaia 1951, 235) Sofia wrote to lulia on January 19, 1869, as she was preparing to leave Russia accompanied by Volodya and Anuyta. ${ }^{16}$ After a short stay in Vienna, the trio separated: Sofia went to study mathematics in Heidelberg, Anyuta moved on to Paris to pursue her interests in literary work, while Volodya initially stayed on in Vienna.

After overcoming many obstacles, Sofia was finally enrolled as a student at Heidelberg University and spent her first three semesters (1869-1870), studying physics and mathematics. As she wrote to lulia, her admission to the university was an exception, granted on the grounds of her being married into a well- known scientific family at the time. ${ }^{17}$ Iulia, who was also accepted at Heidelberg in the fall of 1869 , has painted a rosy picture of their study days in her memoir:

The three of us would take walks in the vicinity of Heidelberg, go quite a distance and, finding ourselves on a flat stretch of road, the two of us, Sofa and I would take off at a dead run, exactly like two little children. Dear heavens! How much gaiety and happiness there is in these memories of the first period of our university life! (Lermontova 1951, $382)^{18}$

The group of Russian emigrés in Heidelberg went through many changes. They welcomed one more runaway girl from Russia, Zhanna, ${ }^{19}$ while Anyuta also joined them from Paris. Natalia Armfeldt ${ }^{20}$, lulia's cousin Olga and Zhanna's sister Sofia would also occasionally visit. This was a lively commune of women who later became ardent political activists, as well as stellar scientists in their respective fields, however the Heidelberg flat became a crowded site of dispute and the man who had sacrificed himself for the cause of women had to bow out in the end:

Sonya's sister and her friend Inez ${ }^{21}$ arrived at the beginning of the winter. They were both many years our seniors. As we had not much room, Kovalevsky decided to move and give up his room to them. Sonya visited him very often, spending the whole day with him, and they often took walks together without us. It naturally was not pleasant for them to be surrounded by so many women, especially as the two recent arrivals were not always amiable toward Kovalevsky. They had their peculiar ideas, and thought that as the marriage, after all, was only a formal one, Kovalevsky ought not to try to give a more 
intimate aspect to his intercourse with his wife. This interference caused irritation and spoiled the good understanding of our little circle. (Lermontova 1951, 384) ${ }^{22}$

On completing their studies at Heidelberg, both Sofia and lulia decided to move to Berlin in pursue of a PhD. Although Berlin University was closed to women, Sofia wanted to be supervised by Professor Karl Weierstrass, a major figure in modern mathematical analysis: 'I consider Weierstrass himself one of the greatest mathematicians of all time, and indisputably the most outstanding of those alive today' she wrote in a short autobiographical sketch, in May 1890. (Kovalevskaya 1978 [1891] 218) The two young women led a very secluded life, totally devoted to the hard work of doctoral studies: 'Sonia used to sit bent over her papers all day long, I was at the laboratory till the evening, and after a hurried supper we resumed our work', lulia wrote in her memoir. (Lermontova 1951, 378) ${ }^{23}$ But the hard monotony of doctoral life was interrupted by the news that Sofia's sister Anyuta was heavily involved in the events of the Paris Commune. As soon as they heard the news, Sofia and Volodya headed to Paris, to see how they could support Anyuta and her lover Victor Jaclard during these turbulent times: 'Very many of our good friends have been wounded or killed' Volodya wrote to his brother Aleksader on May 28, 1871 from Paris. (in Koblitz 1993, 110). ${ }^{24}$ Anyuta and Victor were not amongst those who were wounded or killed, but they were both persecuted. It was only after the intervention of Anyuta's highly connected Russian family that they eventually escaped France and found themselves as political exiles in Zurich. The events of the Paris Commune left a lasting impression on Sofia. According to Leffler she intended to write a novel, The Sisters Raevsky under the Commune, but her untimely death cancelled such writing plans, amongst many other projects that remained unfinished during her life. ${ }^{25}$ There have been many speculations and discussions about Sofia's politics and her close involvement in the radical circles of her geographies and times. In a letter to the German socialist democrat Georg Vollmar, whom she had met in Paris, Sofia had written that she was never sure whether her devotion to mathematics was the right choice in the context of the social upheavals of her times. Despite her ambivalence however, the rationale for her decision was that 'the resolution of the social question seemed to me so far away and murky, that completely devoting oneself to the issue did not seem worthwhile for a serious scholar capable of doing something better.' (Kovaleskaia 1951, 263) ${ }^{26}$

After her experience of the political turbulence in Paris, Sofia returned to her studies in Berlin and by 1874 she had written three papers 'each one of which deserved a doctoral degree' according to Elizaveta Litvinova's ${ }^{27}$ memoir. (1894, in Koblitz 1993, 121-22). Together with Weierstrass they decided to submit this work to the University of Göttingen. The choice was made because Weierstrass knew mathematicians there, the University was known for awarding degrees to foreigners in absentia, while they had already granted a doctorate to a woman, Dorothea von Rodde-Schlözer ${ }^{28}$ in 1787 . The cover letter of her thesis submission summarizes Sofia's 'technologies of resistance' most eloquently. One of the greatest mathematical minds of her time had to excuse herself for daring submitting a PhD thesis on the grounds of pleasing her friends and to do so in absentia because she felt nervous in the presence of men and was not mastering the German language:

The very reverend Dean will graciously permit me to add something to the letter in which I present myself for admission to the degree of Doctor Phil, in the mathematical faculty [...] It is only a wish to satisfy my dearest friends [...] I wish to give them an incontestable proof 
that, in devoting myself to the study of mathematics, I am following the determined bent of my nature, and that, moreover, this study is not without result. At the same time I hope the very reverend Dean will not misconstrue me if I acknowledge openly that I do not know whether I have sufficient aplomb to undergo an examen rigorosum, and I fear that the unusual position, and having to answer, face to face, men with whom I am altogether unacquainted, would confuse me, although I know the examiners would do all they could for me. In addition to this, I speak German very badly. (Leffler 1895b, 188) ${ }^{29}$

What a shameful light this document casts on the male academic culture which Sofia felt obliged to propriate-a really dark shadow in the history of science. And yet Sofia got her PhD cum laude, although it took her ten years to actually become an academic. On returning to Russia, personal life took precedence. After three years of emotional tensions, Sofia and Volodya turned their fictitious marriage into a real one and they had a daughter, Fufa. ${ }^{30}$ Things did not go very well on the practical side of their household, however. Despite their illustrious scientific achievements neither of them could get a position in Russia, Sofia because of her gender and Volodya because of his radical political views. Sofia turned to journalistic and literary writings and it is from her largely auto/biographical novel, Nihilist Girl that we can get a glimpse of her overall state of mind at the time:

I was twenty-two years old when I moved to Petersburg. Three months earlier I had graduated from a university abroad and returned to Russia, doctoral degree in hand. After five years of isolated, cloistered existence in a small university town, life in Petersburg immediately enveloped and, as it were, intoxicated me. Putting aside for a while the consideration of analytic functions, space and the four dimensions, which had so recently obsessed me, I threw myself into new interests. I made acquaintances left and right. I tried to penetrate the most varied circles. With greedy curiosity I turned my attention to all the essentially empty but initially so engaging manifestations of the complex hubbub that we call life in Petersburg. (Kovalevskaya $2001[1892], 3)^{31}$

It seems that the new social life totally intoxicated the young scientists. When Sofia's parents died, they decided to invest Sofia's inheritance in risky and eventually disastrous projects. The result was tragic: Volodya went bankrupt and Sofia went away to Europe to resume her scientific career. It was in Paris that she received the heart-breaking news of her husband's suicide in April 1883: 'Write Sofa that my constant thought was about her and how very wrong I was before her, and how I spoiled her life, which except for me would have been bright and happy'32 Volodya wrote to his brother in his farewell letter. (in Kennedy 1983, 215-6) His last wish was that Anyuta look after Sofia and their little daughter, Fufa. But Anyuta was the second great loss that Sofia suffered some years later. In the summer of 1887, her sister was forced to leave Russia because of her political views, while she was already very ill; she died in Paris soon after, in the fall of 1887.

When her sister died, Sofia was in Stockholm, where she had accepted a position at the newly founded university, the first woman to get a university-level teaching post in modern Europe. Becoming an academic was Sofia's dream, but it took a lot of effort and it was only realized through the concerted efforts of Weierstrass and his former student Gösta Mittag-Leffler (1846-1927), a Swedish mathematician ${ }^{33}$. Weierstrass always believed that Sofia was a star 
mathematician, so he didn't stop supporting her with her PhD publications and with networking in the mathematical world. Gösta had first met Sofia in 1876 during a visit at St Petersburg and had been impressed by her:

What most deeply interested me in St Petersburg was getting to know Madame Kovalewsky. Today [10 February 1876] I spent several hours at her house. As a woman, she is fascinating [...] As a scholar she is characterized by her unusual clarity and precision of expression. The depth of her knowledge becomes clear then and I understand fully why Weierstrass considers her the most gifted of his students. (MittagLeffler 1923, 172) ${ }^{34}$

Gösta met Sofia again in the beginning of 1880, this time attending her talk for the Sixth Congress of Natural Scientists in St Petersburg. Sofia's paper was very well received. According to Litvinova's biography, 'her ideas were distinguished by their novelty and freshness.' (1894 in Koblitz 1993, 144) Gösta wrote that although Sofia had left mathematical work for so long, she showed that 'she was born a mathematician and that in resuming her studies she had found a moral equilibrium' $(1923,173)$. At that time, Gösta was professor of mathematics at Helsinki University and through this position he started trying to open a place for Sofia at his university. But Sofia's reputation as 'a nihilist' blocked this plan as the Finnish did not want trouble: 'All my university people know about your exceptional talent [...] if you were a Finn, or belonged to any other nation except Russia, you would without doubt be invited here', Gösta wrote to Sofia in one of the 420 letters and notes that they exchanged between 1880 and 1890. (in Kennedy 1983, 204-5) ${ }^{35}$ But as soon as Gösta took a chair of mathematics at the new Stockholm university, he renewed his efforts to find an academic position for Sofia there. Sofia's letters express her disappointment, as well as her overall disillusion at the possibility of ever becoming an academic. This is what she wrote to Gösta in June 1881: 'As to your excellent plans with regard to Helsinki ... I never seriously believed in them in spite of very much wanting them to work out. I also do not intend to place too much hope in Stockholm; although I admit that I would be ecstatic if I were given the opportunity'. (in Koblitz 1993, 156) ${ }^{36}$

As Arild Stubhaug in his biography of Gösta has observed, Sofia's appointment in Stockholm was part of Gösta's wider project of consolidating and strengthening Sweden's position in the world of mathematics. (2010, 299) Apart from championing and supporting Sofia's appointment, Gösta was collecting funds not only to cover her salary for five years, but also for inviting guest lecturers from all over Europe in Stockholm. Their doctoral advisor, Weierstrass, was amongst the first to visit in the fall of 1884, the same year that Sofia was appointed. In joining the university, Sofia was also invited to the editorial board of Acta Mathematica, the journal that Gösta had founded in 1882. Sofia'a presence at the editorial board greatly contributed to the international status of the journal, which started receiving important submissions from Russian, German and French mathematicians. Not only did Sofia present and often translate Russian submissions, but she was also liaising with top mathematicians in Europe: 'Monsieur, [...] let me ask if you are aware of M. Weierstrass' treatment of the same question ${ }^{\prime 37}$ she wrote to Henri Poincare in May 1887, advising him about a mathematical demonstration that was part of Weierstrass' course, well known to his students, although never published. 
Thus, Sofia's appointment went well beyond Gösta's admiration for her, as well as his fervour to please Weierstrass. It was more an effect of the fact that he "had a genius for organization and for mathematical "intelligencing" [...] he brought mainstream European mathematics to Scandinavia and Scandinavian mathematicians to the attention of the rest of Europe'. (Koblitz 1993, 161-2) But although Gösta was fully convinced that Sofia's appointment would make a great contribution to a newly founded small mathematical department, Sofia herself, was highly ambivalent about her ability to deliver. This is how she responded to Gösta's formal invitation to visit Stockholm as a private docent, that is deliver lectures with no salary and no official status for a year as a probation period for her subsequent appointment subject to an academic review:

I cannot sufficiently express my gratitude for the friendship you have always shown me, nor tell you how happy I am to enter upon a career, which has been the object of my constant desires. Nevertheless, I must not conceal from you, that in many respects I do not feel myself qualified for the duties of a lecturer, and I am almost afraid that, in spite of your kind predilection for me, you will be quite disappointed with my performances, when you come to see them at close quarters. (in Cooke 1984, 101-102) ) $^{38}$

Sofia's ambivalence vis-à-vis one of her wildest dreams was real rather than rhetorical, since in the same letter above, she suggested that perhaps she should spend the autumn months in Berlin with Weierstrass, preparing for her lectures in Stockholm. As Litvinova commented in her memoir, talented women who break new paths would always go through such states of confusion and uncertainty, while 'the thought that he was not well enough prepared to assume the duties of a docent would not even pass through the mind of the most mediocre man' $(1894$, in Koblitz 1993, 176), then and now, I would add. Sofia's reception in Stockholm where she arrived on November 17, 1883 was warm and celebratory. One of Stockholm's progressive newspapers saluted the arrival of 'a princess of science'. Sofia's response was bitter and ironic: 'Look at that. I've been made into a princess! It would have been better if they had given me a salary'39 she wrote to Aleksader Kovalevskii. (Kovaleskaia 1951, 235)

But Despite Sofia's hesitations and fears her first course on partial differential equations in the spring term of 1884 was a success. Although she initially delivered her lectures in German, she very soon managed to familiarize herself with the Swedish language and immersed herself in the seminars and research culture of the mathematical circles there. By the end of the term Gösta was able to finalize her appointment as 'extraordinary professor' of superior analysis for a period of five years. Gösta was only able to succeed in this by withdrawing his opposition to the appointment of two ordinary professors from the Uppsala school: 'you see how expensive I am, I went for two "ordinaries"' 40 , Sofia wrote sarcastically to Aleksader in May 1984. (Kovaleskaia 1951, 281) In his letter of support to the university authorities, Gösta did not only praise her teaching, but also highlighted 'the impression made on intelligent circles in Stockholm by the sympathetic personality and genius of the speaker' $(1892-3,87)$.

Sofia's personality was indeed hugely appreciated by Gösta's family, who welcomed and generously hosted her during the first months in Sweden. Sofia became particularly close to Gösta's sister Anna Carlotta, with whom she conversed, went out to theatres and other cultural events, travelled, and eventually co-wrote two plays. ${ }^{41}$ 'Her power of understanding and sympathizing with the thoughts of others was so exceptional, her praise when she was 
pleased so warm and enthusiastic, her criticism so just', Anna Carlotta wrote, in appreciation of the lasting influence that Sofia had upon her literary work. (1895b, 208-9) After three years in Stockholm on her own, Sofia was finally able to bring her daughter Fufa over from Russia. In her letters we can see the emotional strain and dilemmas of combining a career in mathematics with being the mother of a young child. This is how she defended her decision to leave Fufa in Moscow with her friend lulia: 'I do not think it would be in the child's interest to take her away from this place, where she is well cared for, and to carry her back with me to Stockholm, where nothing is prepared for her, and where I shall have to devote my whole time and energy to my new duties'. (Kovaleskaia 1951, 283-284) ${ }^{42}$ Sofia was fully aware that she might be criticized as an indifferent mother, but she was determined to do what she thought was best for her child and not to let 'the shadow of a wish to play the part of a good mother in the eyes of Stockholm petticoats influence me in the least'.(ibid.)

Later on in life, Fufa would recall her mother's attempts to make her feel at home in a foreign country. One of her fondest memories was the time when her mother was preparing her Recollections of Childhood for publication. While organizing reading sessions for her women friends, she would also allow her little daughter to be in the audience: 'I started to think about her more as a person who had experienced much in her own right rather than as just my mother' Fufa wrote. (Kovaleskaia 1951, 367) ${ }^{43}$ As her biographers have shown, Sofia's solitary life was illuminated and brightened by the presence of her daughter. 'Gave the first lecture today, I don't know whether it was good or bad, but I know that it was very sad to go home and feel so lonely in this world' she wrote in her diary, on January 30, 1884. (Kovaleskaia 1951, $177)^{44}$ It was not easy to be a single mother and professor of mathematics at the turn of the nineteenth century, living away from your country and your friends. But Sofia's way of combining her private life with an illustrious career in mathematics has been and continues to be a source of inspiration for women scientists, as Koblitz has observed. $(1989,190)$

As already noted above, Sofia was a member of the Paris mathematical society since 1882 and she got to know some of the best French mathematicians of her time: 'Picard and Poincaré' 'are the most gifted of the new generation of mathematicians in all Europe' she wrote in her autobiographical sketch in May, 1890. (Kovalevskaya 1978 [1891], 221) It was in Paris that she lived the highlight of her career when in December 1888, she received the Prix Bordin of the French Academy of Sciences for her paper 'On the Problem of the Rotation of a solid Body about a Fixed Point.' (Kovalevskaya 1889) So excellent was the contribution that the jury of the Academy decided to increase the value of the prize from 3,000 to 5,000 francs. When she refined the paper in the following year, the Swedish Academy of Scienses honoured her with an additional prize of 1,500 kroner (Kovalevskaya 1890) and she was finally elected as a lifetime professor at Stockholm University. The year ended with an exceptional honour from her own country: Sofia became the first woman to be elected as a corresponding member of the Imperial Academy of Sciences nominated by the famous Russian mathematician Chebyshev.

Sofia spent the last year of her life in full recognition of her extraordinary achievements in mathematics, while her personal life was full of travelling, meetings with famous mathematicians and socializing with beloved friends in Sweden and France. Some of her biographers also refer to a new romance in her life. Leaving aside the question of whether Maksim Kovalevskii ${ }^{45}$ was the man with whom she would eventually live happily ever after, 
what happened, was that she caught pneumonia while travelling from Nice to Stockholm via Paris and Berlin and she died in her house in early February 1891. 'Too much happiness' became the discourse par excellence in the mythographies that have revolved around her life and which still keep obscuring a deeper understanding of her life as 'a design that has a meaning' (Arendt 1968, 105), a theme that I will now turn to in the next section of the paper.

\section{Traces of the self}

Each of Sofia's numerous friends preserved in his or her memory a different image, because to each one she presented herself in a completely different light. But there was not the least falseness in this; it was just that her rich nature gave to the person who interested her at that moment exactly what seemed to her to suit that person. Her interest in the given personality was exclusive; it did not permit her to involve herself with others at the same time. (Mendelson 1912 in Koblitz 1993, 164) ${ }^{46}$

This extract from Marie Jankowska-Mendelson's reminiscences nicely summarizes Sofia's multi-faceted character and personality that kept fascinating her friends and collaborators during her life and beyond. How can then Sofia's life be perceived and understood beyond the discourse of [un]happiness? Life-stories create a design, a discursive unity that carries meaning, Arendt has argued, although this meaning is never fixed, but rather felt and lived: 'it is true that storytelling reveals meaning without committing the error of defining it, that it brings about consent and reconciliation with things as they really are' $(1968,105)$. As I have shown however in the previous section Sofia's life narrative has been drawn, redrawn, translated and transcribed so many times that it has eventually become a collage of moments, a labyrinth of winding passages, narrow alleys, and abrupt deadlocks, a cartography of words and names. After layers of ego documents and their various translations have been assembled, organized, reordered, read, transcribed and effectively rewritten, Sofia's textual self eventually emerges as a palimpsest. How have I navigated this labyrinth and how have I eventually created 'a design that has a meaning'?

As I have written elsewhere, I take the archive as a living organism and thus as a process in becoming. (see Tamboukou 2016) In doing so, I draw on Whitehead's (1985) philosophy of process, wherein 'events' and not material entities are the fundamental elements in the constitution of reality. Events are not mere happenings or occurrences, but eruptions that mark discontinuities and ruptures in our habitual modes of being, seeing and understanding. Events happen and disappear, but they leave traces behind them in objects, bodies, novellas and stories. When we see, read or touch such traces of the past, we feel that we have somehow grasped 'the real', no matter how fleeting or ephemeral such experiences have been. And yet the idea of 'touching the real' is an illusion, Arlette Farge has pithily noted: 'No matter how much the real seems to be there, visible and tangible, it reveals nothing more than its physical presence, and it is naïve to believe that this is its essence'. (Farge 2013, 11) The importance of the archival object, be it a story, an administrative document, a photograph or a piece of string that slips out of an envelope, "lies in the interpretation of its presence, in the search for its complex meaning, in framing its "reality" within systems of symbols - systems for which history attempts to be the grammar', Farge argues. $(2013,12)$ 
This is precisely where creative imagination works: it disentangles the researcher from the material and affective forces of 'the natural presence' and facilitates 'the researcher's cut' (Tamboukou 2014), put simply intellectual interventions and insights that erupt in the middle of entanglements with the archival documents and open up vistas beyond the stubbornness of common-sense notions and perceptions within the archive and beyond. In this light, creative imagination enables the researcher to see things differently and ultimately creates conditions of possibility for critical analyses and interpretations. Here as elsewhere in my work I have drawn of new materialist approaches in feminist science studies to theorize the archive as a laboratory of memory [and forgetting], but also as an experimental time-space continuum, where memory and imagination are brought together in the study and understanding of documents. (see Tamboukou 2019)

It was therefore while trying to imagine Sofia's love for mathematics as a creative force in the process of becoming a mathematician that I started piecing together extracts and fragments of her ego documents. Sometimes it was just the sound of a word that drew me closer to a particular version of translation and not another; other times I was intrigued by simple words or larger chunks of stories that were either included or excluded in the various translations of the same document. When such gaps occurred, I was trying to fill them with other documents, both in Sofia's meta-archive and beyond. I was particularly intrigued by the fact that there were several occasions when citations to Sofia's ego documents were simply missing and archival sources were vague and obscured. It was thus the black box of Sofia's meta-archive that I was trying to open by following all different citations and translations of the same extract, quotation, letter or even whole document, as it was the case with the three translated versions of her early autobiography (Kovalevsky 1895a, Kovalévsky 1895b, Kovalevskaya 1978), the two translated versions of her autobiographical fiction (Kovaleskaia 1895c, Kovalevskaya 2001), as well as the two translated versions of Leffler's memoir (1895a, 1895b).

As I have shown in the previous section, in following tracks and traces of Sofia's life narratives, I have been drawing simultaneously on biographies and memoirs, letters, autobiographies, autobiographical fiction, as well as the edited version of her collected papers. In this archival journey in search of Sofia, there were many grey areas that I was trying to illuminate. I felt for example that the question of why Sofia abandoned mathematics for five years after her PhD was inadequately addressed in all the biographies and memoirs that I read, while it was crystal clear, even in the first pages of The Nihilist girl. Overall, I was partly amused and partly annoyed by the modernist approaches and interpretations of her life and work: the search for a coherent Sofia who lives her life as an 'unloved object' and reaches her death in the pursuit of love and romance; or the girl-genius, who is passionate for mathematics all along and is indifferent to anybody or anything else, including her daughter; or the heroic Sofia who breaks into Paris at the heart of the Commune and then lives her life supporting revolutionary figures, by being entangled herself in civilian disobedience, when for example she gives her passports to fugitives. ${ }^{47}$ In doing this I have been assembling my own meta-archive, which keeps enlarging as I write this paper. In this light Sofia has become 'a narrative persona', a figure with whom I have been in conversation about the central topic of my research: women's struggles in the shadows and margins of mathematical sciences. ${ }^{48}$ 
In the context of Sofia's meta-archive then, Koblitz (2013) has identified two wider circles of mythographies: the European and the Russian. In the European myths, Sofia is presented as a woman in search of love and happiness that she was unable to find, no matter her success in the world of mathematics. In the Russian mythographies, Sofia appears as a cold woman, indifferent to her husband's love and only interested in the advancement of her career. Although I am in tune with Koblitz's project of demystifying Sofia, my view is that the overarching myth around Sofia is the search for coherence in her stories and in her life. The fragmented nature of her archive has actually confirmed my conviction that the search for coherence is absolutely pointless and conceptually misguided, when trying to understand processes of becoming a woman mathematician.

In lieu of coherence I have enjoyed working with Sofia's ego documents as 'portraits of moments', a configuration emerging from Arendt's biography of Rahel Varnhagen: 'I want a letter to be the portrait of a moment: that in which it is written'. (in Weissberg 2000, 11). Such moments seized in the notes of a diary entry, a letter, a novel or an autobiographical memory allow for the unrepeatable uniqueness of the biographical subject, to emerge. In writing Varnhagen's life 'from within' (ibid.), Arendt did not discuss external facts, unless they were absolutely necessary, but she did not write within the biographical discourse of introspection either. She was interested in the life and actions of the mind, not of the soul or the psyche. Following Arendt's idea of 'writing a life from within' (ibid.), I have not attempted to impose a plot on Sofia's 'portraits of moments'. In searching traces of Sofia's 'vita activa and vita contemplativa' (Arendt 1998), I have also refrained from investing my archival figure with meanings she might neither recognize, nor understand, pretending to know better than her, how she felt or what 'she really wanted'. How to keep psychology or psychoanalysis at bay while at the same time writing about the subject's inner life-Arendt's suggestion of what biography should be about-has been of course a difficult and risky endeavour, but still an exciting path to follow in life writing.

\section{Re-imagining Sofia}

In this paper I have looked back at my research on Sofia Kovalevskaya's meta-archive, addressing questions arising from working with fragmented, inaccessible, translated and dispersed auto/biographical documents. Taking the archive as 'an event' and as a process in becoming, I have discussed the importance of imagination in forming entanglements between the researcher and her archival figures. As Whitehead has pithily noted: 'The philosophies of substance presuppose a subject which then encounters a datum and then reacts to the datum' $(1985,155)$ My experience in Sofia's meta-archive could not fit in this configuration, since 'my datum' was lost, blurred and fragmented and the only way of reacting to it would be either simulation of already existing discourses and narratives, or desperation and abandonment of the effort altogether. But in my perplexity with this impossible archive, I was drawn by insights of process philosophies which 'presuppose a datum, which is met with feelings, and progressively attains the unity of a subject' (ibid.) It was by way of feeling Sofia's ego documents through the sounds of words, the rhythm of language and the vibratory energy of re-imagining women in mathematics that my perception and understanding eventually took form and it is only within my entanglement in the maze of her archival documents that I have seen and recognized Sofia. ${ }^{49}$ In lieu of the separation between myself as the subject/researcher and Sofia as the object of the research, we have 
both become 'superjects' (ibid.) entangled in the archive and I am now inviting the reader in this risky and yet affective process of recognising and understanding.

\section{References}

Arendt. 1968 [1955]. Men in Dark Times. New York: Harvest Books.

Arendt, H., 1998. The Human Condition. Chicago: University of Chicago Press.

Audin, Michèle. 2011. Remembering Sofya Kovaleskaya, (M. Audin, transl.) London: Springer.

Casey, Edward, S. 1976. Imagining: A Phenomenological Study. Bloomington: Indiana University Press.

Cooke, Roger. 1984. The Mathematics of Sonya Kovalevskaya, Springer-Verlag.

Farge, Arlette 2013 [1989]. The Allure of the Archives. Trans. T.Scott-Railton. New Haven: Yale University Press.

Guaraldo, Olivia. 2001. Storylines: Politics, History and Narrative from an Arendtian Perspective. Jyväskyla: SoPhi.

Halmos, Paul. 1985. I want to become a mathematician: an automathography. New York: Springer.

Kennedy, Don H. 1983. Little Sparrow: A portrait of Sophia Kovalevskaya. Athens OH: Ohio Univ. Press.

Koblitz, Ann Hibner. 1988. 'Science, Women, and the Russian Intelligentsia: The Generation of the 1860s' The History of Science Society, 79 (2), 208-226.

Koblitz, Ann Hibner. 1989. 'Career and Home Life in the1880s: The Choices of Mathematician Sofia Kovalevskaia'. In Pnina G. Abir-am and Dorinda Outram (eds). Uneasy Careers and Intimate Lives: Women in Science, 1789, 1979. New Brunswick and London: Rutgers University Press, 172-190.

Koblitz, Ann Hibner. 1993 [1983]. A Convergence of Lives: Sofia Kovalevskaia: Scientist, Writer, revolutionary. New Brunswick and London: Rutgers University Press.

Koblitz, Ann Hibner. 2013 [2000]. Science, Women and Revolution in Russia. London and New York: Routledge.

Kochina, Pelayeva. 1985. Love and Mathematics: Sofya Kovalevskaya. Transl. Michael Burov. Moscow: Mir Publishers.

Kovaleskaia, Sofe, Vasilevna. 1951. Memories and Letters [Коваевской, Софье, В. Bосnоминанця и nucbMa]. Moscow: AN SSSR.

Kovaleskaia, Sofia Vladimirovna (Fufa). 1951. 'Memories of my mother' [Bосnоминанця о материъ]. In Kovaleskaia, Sofe, Memories and Letters. Moscow: AN SSSR, 360-68.

Kowalevski, Sophie. 1889. 'Sur le probleme de la rotation d'un corps solide autour d'un point fixe. Acta Mathematica 12, H.2, 177-232.

Kowalevski, Sophie. 1890. 'Sur une propriété du système d'équations différentielles qui définit la rotation d'un corps solide autour d'un point fixe' Acta Mathematica 14, 81-93.

Kovalevskaya, Sofya. 1891. 'An Autobiographical Sketch' in Russkaya starina, No1, 1891, 450-463, trans. Beatrice Stillman in Kovalevskaya, Sofya, 1978. A Russian Childhood. New York: Springer-Verlag, 213-229.

Kovalevsky, Sonia. 1895a. 'Reminiscences of Childhood [Life in Russia: The sisters Rajevski]' In Sonia Kovalevsky. Biography and Autobiography. Trans. Louise Von Cossel. London: Walter Scott, 167-317. 
Kovalévsky, Sónya. 1895b. 'Recollections of Childhood'. Trans. Isabel F. Hapgood. In Sónya Kovalévsky, Her Recollections of Childhood. With a Biography. New York: The Century Co. 1-151.

Kovaleskaia. Sofia, Vasilevna. 1895c. Vera Barantzova. Trans. Sergius Stepnak and William Westall. London: Ward and Downey.

Kovalevskaya, Sofya. 1978 [1895]. A Russian Childhood. Trans. Beatrice Stillman. New York: Springer-Verlag.

Kovalevskaya, Sofya. 2001. [1892] Nihilist Girl. Trans. Natasha Kolchevska with Mary Zirin. New York: The Modern Language Association of America.

Kovalevskii, Aleksader, O. and Vladimir, O. Kovalevskii. 1948. 'Letters'. In Scientific Legacy [Nauchnoe nasledstvo]. Moscow: AN SSSR, Vol.I, 185-423.

Kristeva, Julia. 2001. Life is a Narrative, Frank Collins (trans.) Toronto: University of Toronto Press.

Leffler, Anna Carlotta. 1895a. 'Memoir'. In Sonia Kovalevsky. Biography and Autobiography. Trans. Louise Von Cossel. London: Walter Scott, 1-166.

Leffler, Anna Carlotta. 1895b. 'A Biography'. Trans. A.M. Clive Bayley. In Sónya Kovalévsky, Her Recollections of Childhood. With a Biography. New York: The Century Co. 154-303.

Lermontova, Iulia, V. 1951. 'Memories of Sofia Kovalevskaya' [Bocnoминанця O Софье Ковадевской']. In Kovaleskaia, Sofe. Memories and Letters. Moscow: AN SSSR, 375-387.

Litvinova, Elizabeta. 1894. S. V. Kovaleskaia: her Life and Scientific Work [S.V. Kovalevskaya: ee zhizn' I nauchnaia deiatel'nost.] St Petersburg: P.P. Soikin, Vol. 83.

Mendelson, Marie. 1912. 'Memories of Sofe Kovalevskoi' [Vospominaniia o Sofe Kovalevskoi'. Trans. L. Krukovskaia. Sovrememmyi mir 2, 134-76.

Mittag-Leffler, Gösta [1892-93] Sophie Kovalevsky. Notice biographique. Acta Mathematica 16, 385-392.

Mittag-Leffler, Gösta. 1923. 'Weierstrass et Sonja Kowalewsky'. Acta Mathematica, 39, 133198.

Moore, Niamh Andrea Salter, Liz Stanley and Maria Tamboukou. 2016. The Archive Project:Archival Research in the Social Sciences. London: Routledge.

Munro, Alice. 2009. Too Much Happiness. London: Vintage.

Musabekov, Iu, S. 1967. Iulia Vsevolodovna Lermontova 1846-1919. Moscow: Nauka.

Rosslyn, Wendy (ed.). 2003. 'Women in Russia (1700-1825): Recent Research', in Women and Gender in 18th-Century Russia, ed. W. Rosslyn. Aldershot: Ashgate.

Spicci, Joan. 2002. Beyond the Limit: The Dream of Sofya Kovalevskaya. London: Forge Books.

Stubhaug, Arild. 2010. Gösta Mittag-Leffler: A Man of Conviction. Trans. Tiina Nunnally. London: Springer.

Tamboukou, Maria. 2014. 'Archival research: unravelling space/time/matter entanglements and fragments, Qualitative Research, 14(5), 617-633.

Tamboukou, Maria. 2016. Feeling Narrative in the Archive: The Question of Serendipity. Qualitative Research 16(2), 151-166.

Tamboukou, Maria. 2018. 'Rethinking the subject in feminist research: narrative personae and stories of "the real"', Textual Practice, 32(6), 939-955.

Tamboukou, Maria. 2019. (2019) 'New Materialisms in the Archive: in the mode of an œuvre à faire', in Mai: Feminism and Visual Culture, https://maifeminism.com/newmaterialisms-in-the-archive-in-the-mode-of-an-oeuvre-a-faire/ 
Tamboukou, Maria. 2020. 'Archives, Genealogies and Narratives in Women Workers' Education', in Women's History Review 29(3), 396-412.

Weissberg, Liliane. 2000. 'Introduction: Hannah Arendt, Rahel Varnhagen and the Writing of (Auto)biography'. In: Hannah Arendt Rahel Varnhagen: The Life of a Jewess, ed.Liliane Weissberg. Richard and Clara Winston. Baltimore and London: The Johns Hopkins University Press, 3-69.

Whitehead, Alfred, N., 1985[1929]. Process and Reality [Corrected Edition], eds. Griffin D. R. and Sheburne D.W. New York: The Free Press.

\footnotetext{
${ }^{1}$ There are many differentiations of Sofia Kovalevskaya's names, as well as different spellings of them in the literature: Софье, Софа, Sophia, Sofya, Sofia, Sofe, Sónya, Sonia, Sonja, Ковадевской, Kovalevski, Kovalévsky, Kovalevskaia, Kovalevskaya, Kovalevskoi, Kowalewsky. For the sake of simplicity and clarity I will use her first name Sofia when referring to her throughout the paper. The bibliographical references will follow their specific spellings.

${ }^{2}$ Anna Vasilyevna Korvin-Krukovskaya (1843-1887) was a socialist and feminist revolutionary. After following her sister Sofia in Europe, she eventually settled in Paris where she met Victor Jaclard, whom she eventually married. For more biographical details, see Kennedy 1983, Koblitz 1993 and Spicci 2002. I will refer to her as Anyuta throughout the paper, following Sofia's preference.

${ }^{3}$ Vladimir Onufrievich Kovalevskii (1842-1883) came from a Russian-Polish land-owners' family. He got involved in the Russian radical circles and was the first to translate and publish Darwin's work in Russian. The fact that a volume of Kovalevskii's complete works was compiled by Stephen J. Gould, a well known palaeontologist and historian of science, (1980) is an indicator of his highly regarded place in palaeontology. For more biographical details and references, see Koblitz 1993 and Kennedy 1983. I will refer to him as 'Volodya' throughout the text, following Sofia's preference for his name.

${ }^{4}$ For an extended discussion of 'meta-archives' see Moore et al., 2016.

${ }^{5}$ For more details about the project, see https://sites.google.com/view/numbersandnarratives/a-feministgenealogy-of-automathographies [Accessed 15-5-2020]

${ }^{6}$ For a full list of the Russian and Swedish archives, see: https://sites.google.com/view/numbersandnarratives/a-feminist-genealogy-of-automathographies/sofyakovalevskaya/archival-sources [Accessed 16-5-2020]

${ }^{7}$ For an extended philosophical discussion of Arendt's take on life narratives, see Kristeva 2001 and Guaraldo 2001.

${ }^{8}$ Memories of Sofia's last words, also cited in Audin 2011, 139, 218.

9 'Too much happiness' has even become the title of a novella and a book by Nobel laureate writer, Alice Munro (2009).

${ }^{10}$ Kovalevskaya 1978, 53. Also in different translations: Kovalevsky 1895a, 7; 1895b, 173.

${ }^{11}$ Lermontova's memoir was initially written at the request of Anna Carlotta Leffler and was folded in her own biography of Sofia (1895a, 1895b). Throughout the paper I will indicate all different translations and citations that I have encountered in working with Sofia's meta-archive.

12 For a biography of Lermontova, see Musabekov 1967.

${ }^{13}$ See also Leffler 1895a, 11.

${ }^{14}$ For more details about the 1860s radical movement in Russia, see Koblitz 1988.

${ }^{15}$ Vladimir eventually got his doctorate from Jena University in 1872.

${ }^{16}$ Shorter extract, also in Koblitz 1993, 87.

${ }^{17}$ Apart from Vladimir, Aleksader Kovalevskii (1840-1901), his elder brother had also studied at the University of Heidelberg.

18 Also in Koblitz 1993, 92; Leffler 1895a, 27; 1895b, 173; Kennedy 1983, 125

${ }^{19}$ Anna Mikhailovna Enreinova (1844-1919) was the first woman to get a PhD in jurisprudence.

${ }^{20}$ Natalia Armfelt (1852-1887) joined revolutionary groups, who resorted to political violence in opposition to the Tsar's regime. She was exiled in Siberia where she died.

${ }^{21}$ Pseudonym for Enreinova in Iulia Lermontova's memoir
} 
${ }^{22}$ See also, Koblitz 1993, 93; Leffler 1895a, 29-30; 1895b, 175 and Kennedy 1983, 130.

${ }^{23}$ See also Leffler 1895a, 37; 1895b, 180; Kennedy 1983, 144 and Koblitz 1993, 102.

${ }^{24}$ Whole letter in Kovalevskie, 1948, 251-2.

${ }^{25}$ See Leffler 1895a, 44; 1895b, 185. Sofia's childhood memoirs were first published as 'The Sisters Rajevski' (in Kovalevsky 1895a)

${ }^{26}$ Sofia to Vollmar, letter dated May 4, 1882. See also Koblitz 1993, 167.

${ }^{27}$ Elizaveta Fedorovna Litvinova (1845-1919), also got a doctorate in mathematics from the University of Bern in 1848. For biographical details about Litvinova, see Koblitz 1984.

${ }^{28}$ Dorothea von Rodde-Schlözer (1770 -1825) was the first woman in Germany to receive a PhD in philosophy, in 1787.

${ }^{29}$ See also Leffler 1895a, 48-49; Koblitz 1993, 122-23.

${ }^{30}$ Nickname for Sofia Vladimirovna Kovalevskaya, Doctor of Medicine, (1878-1952). After her mother's death Fufa lived with the Gyldéns until she finished secondary school in Stockholm and then returned to live with lulia in Russia. She became a doctor and worked for the Red Cross in Russia and abroad. After her retirement she became a medical librarian and translator and she got very much involved in publishing her mother's literary work.

${ }^{31}$ Also in Kovalevskaia 1895c, 1-2.

32 Vladimir [Volodya] to Aleksader, unsent letter dated, February 1, 1883. In Kovalevskie 1948, 385. Also cited in Koblitz 1993, 171.

${ }^{33}$ Gösta Mittag-Leffler (1846-1927) was a talented Swedish mathematician. He founded the journal Acta Mathematica and the Mathematics Institute of the Swedish Academy of Sciences that bears his name. For biographical details, see Stubhaug 2010.

${ }^{34}$ Mittag Leffler to the Swedish mathematician Carl Malmsten. Parts of the letter are cited in Koblitz 1993, 136 and in Kennedy 1983, 184-85.

${ }^{35}$ Mittag-Leffler to Sofia, 23 March 1881, Mittag-Leffler papers, Institute Mittag-Leffler. (MLpapers/IML).

${ }^{36}$ Sofia to Mittag-Leffler, 7 June 1881 (MLpapers/IML).

${ }^{37}$ Sofia to Henri Poincaré, letter dated May 1, 1887. Poincare's papers at the University of Lorraine: http://henripoincarepapers.univ-lorraine.fr/chp/image/kovalevski2ad.jpg [Accessed, November 2, 2018] ${ }^{38}$ Sofia to Mittag-Leffler, letter dated August 28, 1883, (MLpapers/IML). Also in Leffler 1895a, 71; 1895b, 205 and Koblitz 1993, 176.

${ }^{39}$ Sofia to Aleksader, letter dated December 1883. Also in Koblitz 1993, 179; Audin 2011, 129.

${ }^{40}$ Sofia to Aleksader, letter dated May 1884. See also Koblitz 1993, 187.

${ }^{41}$ The Struggle for Happiness: How it was and How it Might Have Been (1887), staged in Moscow in 1895; Till and After Death aka In the Backward Provinces, was a play inspired by one of Anyuta's unfinished manuscripts.

${ }^{42}$ Sofia to Theresa Gyldén, letter dated May 21, 1884. Also cited in Koblitz 1993, 188.

${ }^{43}$ Sofia Vladimirovna Kovaleskaia (Fufa) 'Memories of my mother' in Kovaleskaia 1951, 360-68). Also in Koblitz 1989, 188.

${ }^{44}$ Also cited in Kochina 1985, 131 and in Kennedy 1983, 227 in slightly different translations

${ }^{45}$ Maksim Maksimovich Kovalevsky (1851-1916) was a distant relative of Sofia's late husband. He was a professor of law in Moscow, but was dismissed because of his liberal political views in 1886. Although they had known of each other, their friendship developed in Stockholm in 1888, when he had visited the university for a series of guest lectures there.

${ }^{46}$ Marie Jankowska-Mendelson was a Polish revolutionary whom Sofia met in Paris in 1882 and they became close friends. See Audin 2011, 152 for details of their friendship.

${ }^{47}$ Marie Jankowska-Mendelson often travelled in and out of Poland with Sofia's passport (see Audin 2011, 152)

${ }^{48}$ For an extended discussion of the figure of the narrative persona see Tamboukou 2018.

${ }^{49}$ See Tamboukou 2016, for an elaboration of the idea of 'feeling the archive'. 